\title{
Activation of a prometastatic gene expression program in hypoxic neuroblastoma cells
}

\section{Preamrudee Poomthavorn ${ }^{1,2}$, Sheena HX Wong $_{1,2}^{1,2}$, Sandra Higgins ${ }^{1,2}$, George A Werther, ${ }^{1,2,3}$ and Vincenzo C Russo ${ }^{1,2,3}$}

\footnotetext{
${ }^{1}$ Murdoch Childrens Research Institute, Centre for Hormone Research, Royal Children's Hospital, ${ }^{2}$ Royal Children's Hospital and ${ }^{3}$ Department of Pediatrics, University of Melbourne, Flemington Road, 3052 Parkville, Victoria, Australia

(Correspondence should be addressed to V C Russo at Murdoch Childrens Research Institute, Centre for Hormone Research, Royal Children's Hospital, University of Melbourne; Email: vince.russo@mcri.edu.au)
}

\begin{abstract}
The hypoxia inducible factor- $1 \alpha(\mathrm{HIF} 1 \alpha)$ is a key regulator of oxygen homeostasis, modulating cell survival, and growth in cells exposed to hypoxia. In this study, neuroblastoma (NB) cells SH-SY5Y and SK-N-MC were employed to determine the mechanisms regulating adaptation to hypoxia. NB cells were cultured in a serum-free medium in the presence or absence of $\mathrm{CoCl}_{2}(100 \mu \mathrm{M}$, hypoxia mimic) for up to $48 \mathrm{~h}$. SH-SY5Y and SK-N-MC cell numbers were not affected by $\mathrm{CoCl}_{2}$ treatment, while mitochondrial activity was reduced by $\sim 50 \%$ in SH-SY5Y cells and by $\sim 70 \%$ in SK-N-MC cells. Intracellular accumulation of HIF1 $\alpha$ protein was detected as early as $30 \mathrm{~min}$ of post-hypoxia, followed by the increase of mRNA for vascular endothelial growth factor (VEGF) and nuclear accumulation of the ID1-2 transcription factors by $4 \mathrm{~h}$. In hypoxic SH-SY5Y NB cells, real-time PCR analysis showed that the genes involved in maintenance of cell-cell and cell-matrix interactions (i.e. adenomatosis polyposis coli, E-cadherin, catenin, EphB2, fibronectin-1, HTATIP2, tissue inhibitor of metalloprotease-4) were down-regulated by up to $90 \%$, while genes involved in enhancement of metastatic behavior (integrin a7b1, hepatocyte growth factor receptor, transforming growth factor- $\beta 1$, VEGF, kisspeptin, interleukin-1 $\beta$ ) were dramatically up-regulated above $200 \%$. These changes were all consistent with the induction of epithelialmesenchymal transition. We have thus demonstrated that NB cell adaptation to hypoxia, in addition to the modulation of HIF1 $\alpha$ and VEGF expression and nuclear translocation of ID1 and ID2 transcription factors, involve in the activation of a gene expression program consistent with the pro-metastatic events. These processes are probably responsible for the NB cell transition from an adherent phenotype to a highly migratory, invasive and aggressive NB cell type.
\end{abstract}

Endocrine-Related Cancer (2009) 16 991-1004

\section{Introduction}

Hypoxia can be described as a reduction of oxygen supply below the normal level of tissue oxygen tension (Hockel \& Vaupel 2001). This event may occur in acute or chronic vascular disease, pulmonary disease, and notably in cancer (Carmeliet \& Jain 2000). In hypoxia, cellular mechanisms (i.e. mitochondrial activity) are compromised, and if severe or prolonged may lead to cell death (Semenza 1999, Wenger 2002). Conversely, exposure to hypoxic conditions may activate a number of adaptive/survival cellular responses (Bunn \& Poyton 1996, Semenza 1999,
Wenger 2002, Lee et al. 2004, Wenger et al. 2005). This is the case in solid tumors that become hypoxic because of aberrant newly developed blood vessels and tumor overgrowth, causing inefficient local circulation (Harris 2002, Semenza 2003, Brown \& Wilson 2004).

Although hypoxia is toxic to both cancer cells and normal cells, cancer cells often undergo genetic and adaptive changes that allow them to survive and even proliferate in an hypoxic environment (Harris 2002, Semenza 2003, Brown \& Wilson 2004, Ikeda 2005). These processes contribute to the malignant and aggressive phenotype (Jogi et al. 2003, 2004, Axelson 
et al. 2005, Belozerov \& Van Meir 2005, Kaur et al. 2005, Chen et al. 2006, Holmquist et al. 2006). However, the mechanisms involved are not fully understood.

Mammalian cells, including cancer cells, adapt to hypoxia primarily through a transcriptional response pathway mediated by the hypoxia inducible factors (i.e. HIF1 $\alpha$; Semenza 1998, Wenger 2002, Safran \& Kaelin 2003, Zarember \& Malech 2005). In normoxia HIF $1 \alpha$ protein levels are regulated at transcriptional, via factor inhibiting HIF1, and post-translational levels are regulated via ubiquitination and proteasome degradation of HIF1 $\alpha$ protein (Bunn \& Poyton 1996, Semenza 1999, Wenger 2002, Lee et al. 2004, Mazure et al. 2004, Wenger et al. 2005). In hypoxia, HIF1 $\alpha$ inhibition and degradation are abrogated and this leads to a stable and functional HIF1 $\alpha$ and formation of HIF complexes. These complexes can thus bind to regulatory hypoxia responsive elements (HRE) of genes such as the survival cytokine erythropoietin (EPO) and the angiogenesis factor, vascular endothelial growth factor (VEGF; Semenza 1998, Wenger 2002, Lee et al. 2004).

Neuroblastoma (NB) is the most common neural crest derived extracranial solid tumor of childhood and arises from sympathetic nervous tissue origins (Bown 2001, Brodeur 2003). NB cells vary in relation to their differentiation stage, with aggressive NB tumors deriving from more immature NB cells (Brodeur et al. 1988, Bown 2001, Brodeur 2003, Holmquist et al. 2005, 2006). These NB tumors may be present as phenotypically distinct groups of NB cell types (i.e. neuroblastic, neuroendocrine) organized in lobular structures with a central necrotic/hypoxic zone (Jogi et al. 2002, 2003). Recent evidence has demonstrated that NB cells growing in these necrotic/hypoxic zones undergo a gene expression switch involving decreased expression of neuronal/neuroendocrine marker genes, but induced gene expression of neural crest sympathetic progenitor markers (Jogi et al. 2002, 2003, 2004, Axelson et al. 2005). These data (Jogi et al. 2002, 2003, Axelson et al. 2005), indicating that hypoxia causes dedifferentiation of NB cells to proliferative immature neuroblast-like cells, suggest potential activation of epithelial-mesenchyme transition mechanisms (EMT). Although EMTs occur during critical phases of embryonic development in many animal species, it is now well recognized that EMT is a potential mechanism for cancer progression (Huber et al. 2005, Lee et al. 2006, Thiery \& Sleeman 2006). However, the activation of these events in hypoxic NB cells remains largely undetermined.
In these studies, we have exposed the NB cell lines SH-SY5Y (N type) and the SK-N-MC (S type) to the hypoxia mimicking agent $\mathrm{CoCl}_{2}$ and analyzed cellular and molecular responses to these conditions. We have investigated for the first time whether exposure to hypoxia might produce changes in expression of genes regulating cell-cell and cell-matrix interactions, thus affecting cell adhesion, migration, and metastatic behavior or EMT.

\section{Materials and methods}

\section{Reagents}

Cobalt chloride, $0.01 \%$ sterile poly-L-lysine solution and paraformaldehyde were purchased from Sigma Chemical Co. Total cellular RNA was extracted from cells using RNeasy Mini Kit, Qiagen Pty Ltd. Tissue culture flasks, plates, and chamber slides were purchased from Nunc (Roskilde, Denmark). Chemical reagents (Analar grade) were purchased from BDHMerck Pty Ltd. (Kilsyth, Victoria, Australia). Nitrocellulose membranes $(0.45 \mu \mathrm{M})$ were obtained from Schleicher and Schuell (Dassel, Germany). BioMax films were from Eastman Kodak Company. Intracellular pathway inhibitors AG490 (JAK2 inhibitor), SB203580 (p38 MAPK inhibitor), and U0126 (MEK1/2 inhibitor) were obtained from Calbiochem (Calbiochem-Novabiochem Corporation, San Diego, CA, USA), and the MAPK inhibitor (PD98059) and PI3K inhibitor (LY294002) were purchased from Cell Signaling Technology, Inc. (Beverly, MA, USA).

\section{Cell culture}

The two unrelated human neuroblastoma cell lines, SK-N-SH-SY5Y (Russo et al. 2004a,b) and SK-N-MC (Russo et al. 2004c) were cultured in DMEM (Trace Biosciences, Castle Hill, New South Wales, Australia) supplemented with 10\% FCS (CSL Ltd, Parkville, Victoria, Australia), penicillin (100 U/ml), and streptomycin $(100 \mu \mathrm{g} / \mathrm{ml})$ in a humidified atmosphere containing $5 \% \mathrm{CO}_{2}$ and $95 \%$ air at $37{ }^{\circ} \mathrm{C}$.

\section{Treatment}

When cells reached the required confluence (70\%), they were incubated, for up to $48 \mathrm{~h}$ or as indicated, in the presence or absence of $\mathrm{CoCl}_{2}(100 \mu \mathrm{M})$. Cobalt Chloride concentrations were initially based on those previously published for neuroblastoma cells (Kitamuro et al. 2001) with optimal concentration determine in preliminary experiments in our laboratory (not shown). Media was replaced every $24 \mathrm{~h}$. Cells were then assayed at 24 or $48 \mathrm{~h}$ as indicated. 
Signaling pathway inhibitors were used in some experiments, AG490 at $10 \mu \mathrm{M}, \mathrm{SB} 203580$ at $10 \mu \mathrm{M}$, $\mathrm{U} 0126$ at $25 \mu \mathrm{M}$, PD98059 at $100 \mu \mathrm{M}$, and LY294002 at $100 \mu \mathrm{M}$ for up to $24 \mathrm{~h}$. Concentrations of the above pathway inhibitors were consistent with those previously shown to be effective in SH-SY5Y cells (Russo et al. 2004a,b).

\section{Cell number assay}

Cells were cultured in 24-well plates and upon reaching $70 \%$ confluence were treated as above, for up to $48 \mathrm{~h}$. Cell number was determined by a colorimetric cell number (napthol blue-black, NBB) assay protocol previously described by Janet et al. (1995). Assays were performed at least thrice and samples were run in triplicates.

\section{Mitochondrial activity assays ( \pm inhibitors)}

Cells were cultured in 24-well plates and were then treated as above, for $48 \mathrm{~h}$. Alternatively cells were pretreated for $3 \mathrm{~h}$ with SF media containing the various signaling pathway inhibitors (see above) in the absence or presence of $\mathrm{CoCl}_{2}$. After $3 \mathrm{~h}, \mathrm{CoCl}_{2}$ was added to the cells for $24 \mathrm{~h}$ before being harvested. Cell number was determined by a colorimetric mitochondrial activity (3(4,5-dimethylthiazol-2-yl)2,5-diphenyl-tetrazolium bromide, MTT) assay protocol previously described by Janet et al. (1995). Assays were performed thrice as indicated.

\section{Immunocytochemistry}

Cells were cultured in poly-L-lysine coated 4-well chamber slides and upon reaching $70 \%$ confluence were treated as above, for up to $24 \mathrm{~h}$. Cells were fixed with $4 \%$ paraformaldehyde $(20 \mathrm{~min})$ followed by glycine $100 \mathrm{mM}$ in PBS pH $7.4(10 \mathrm{~min})$ and washed with PBS. Wells/cells were then blocked with $1 \%$ denatured BSA in PBS pH 7.4 (DBSA, denatured by incubation at $60^{\circ} \mathrm{C}$ for $30 \mathrm{~min}$ ) prior to permeabilizing cells with $0.1 \%$ Triton-X 100, $1 \%$ DBSA in PBS pH 7.4 (10 $\mathrm{min})$. The primary antibodies, described below, were applied in $1 \%$ DBSA in PBS and incubated overnight at $4{ }^{\circ} \mathrm{C}$ as indicated.

The monoclonal anti-human HIF1 $\alpha$ antibody (H1 $\alpha 67$ antibody, Novus Biologicals, Inc., Littleton, CO, USA) was used at 1:200. The rabbit anti-human ID1-3 (C-20) antibodies (Santa Cruz Biotechnology, Inc., Santa Cruz, CA, USA) were also used at 1:200. Immunoreactivity for HIF1 $\alpha$ or ID1-3 was detected by the Alexa 488 labeled goat anti-mouse or goat anti-rabbit IgG both at 1:400 (Molecular Probes, Leiden, The Netherlands). Nuclear staining was performed with DAPI (Millipore-Chemicon, Temecula, CA, USA) prior to mounting. Reactive cells were visualized by an inverted $1 \times 70$ u.v. microscope (Olympus). Images were taken at a $10 \times$-magnification objective. Immunocytochemistry was performed thrice and samples were run in duplicate. Omission of primary antibody or mouse or rabbit IgG was used as negative controls (data not shown).

\section{HIF1 $\alpha$ immunoblotting}

SH-SY5Y and SK-N-MC cells were grown as above (T80 $\mathrm{cm}^{2}$ flasks, $\sim 80 \%$ confluency) in the presence or absence of $\mathrm{CoCl}_{2}$ for $15 \mathrm{~min}$ up to $24 \mathrm{~h}$ as indicated. Following the treatment, cells were washed with ice-cold PBS, scraped, centrifuged, and cell pellet extracted with RIPA buffer $(20 \mathrm{mM}$ Tris $\mathrm{pH} 7.4$, $150 \mathrm{mM} \mathrm{NaCl}, 1 \mathrm{mM}$ EDTA, $1 \mathrm{mM}$ EGTA, $0.1 \%$ SDS, $1 \%$ sodium deoxycholate, $1 \%$ Triton $\mathrm{X}-100$, $1 \mathrm{mM}$ sodium orthovanadate) containing Complete protease inhibitor cocktails (Roche). Protein concentration, in cellular extract, was measured with BCA protein assay reagent (Pierce, Rockford, IL, USA). A hundred micrograms of total protein were then fractionated onto 7\% SDS-PAGE under reducing conditions and then transferred to nitrocellulose membranes. HIF1 $\alpha$ was detected by the anti-human HIF1 $\alpha$ antibody. Anti- $\alpha$-tubulin (B-7) antibody (Santa Cruz Biotechnology, Inc.) was utilized to verify equal protein loading across samples. Experiments were performed thrice.

\section{Preparation of RNA for RT-PCR and PCR-array}

Cells were plated out in $\mathrm{T} 80 \mathrm{~cm}^{2}$ flasks and upon reaching $70 \%$ confluence were then cultured as above for up to $24 \mathrm{~h}$. Cells were harvested by trypsin and total RNA was isolated using RNeasy mini kit (Qiagen), including the DNAse treatment.

\section{RT-PCR and DNA sequencing}

cDNA was synthesized from 1 to $2 \mu \mathrm{g}$ of the total RNA using oligo(dT) primer and MuLV-RT (Perkin Elmer, Waltham, MA, USA, Roche) and first stand cDNA synthesis kit (Perkin Elmer), followed by PCR using the Taq Polymerase. Omission of total RNA (water control) or MuLV-RT (genomic DNA control) in the RT reaction was used to assess specific amplification for each gene (not shown). Primers were used as follows: GAPDH (forward 5'-CCATGGCACCGTCAAGGCTGA-3 ${ }^{\prime}$, reverse $5^{\prime}$-GGGCCATCCACAGTCTTCTGG- $3^{\prime}$ ); HIF1 $\alpha$ (forward $5^{\prime}$-GAAAGCGCAAGTCCTCAAAG$3^{\prime}$, reverse $5^{\prime}$-TGGGTAGGAGATGGAGATGC-3'); 

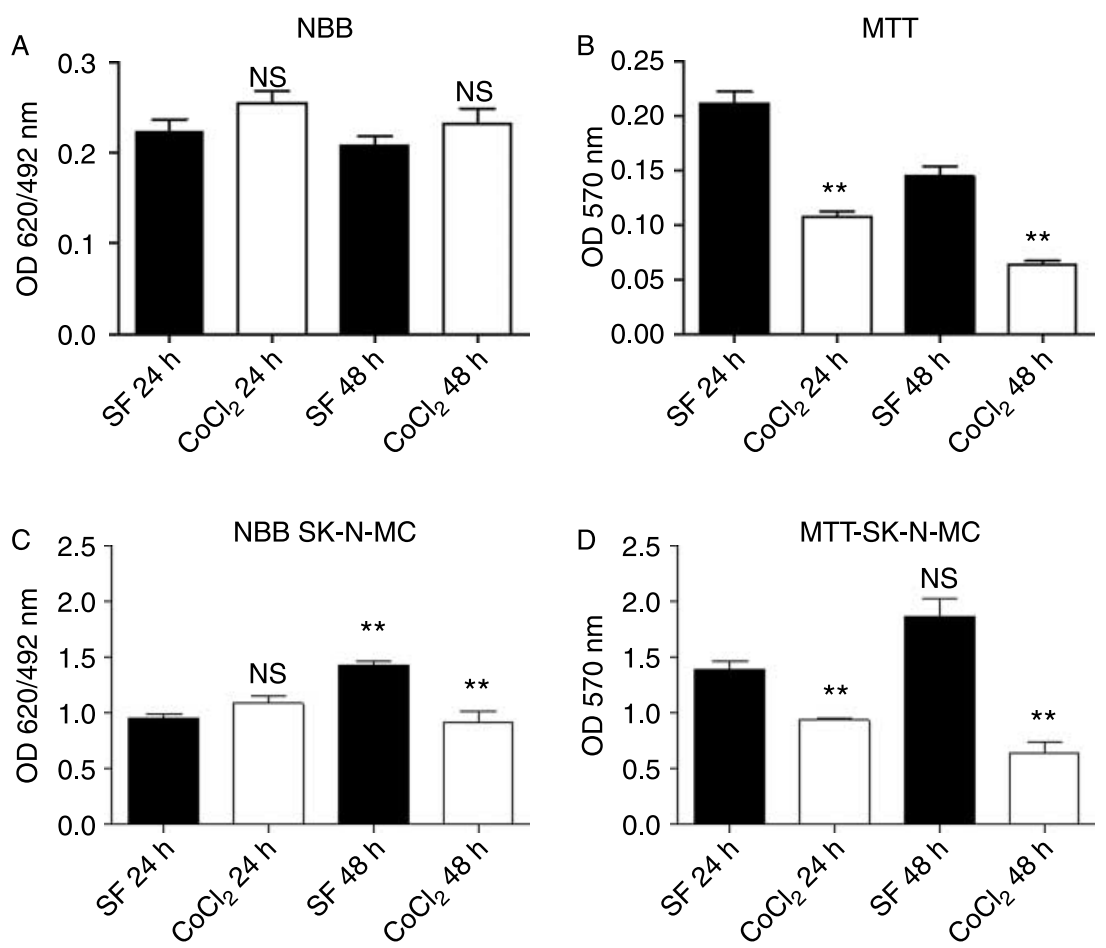

Figure 1 (A-D) Cell mitochondrial activity, but not cell number, is decreased by hypoxia. SH-SY5Y (1AB) and SK-N-MC (1CD) cells were treated with $\mathrm{CoCl}_{2}(100 \mu \mathrm{M})$ and NBB or MTT performed as described in Materials and methods. SH-SY5Y and SK-N-MC cell number was not affected by hypoxia ( $A$ and $C$ ) while mitochondrial activity (B and D) was reduced in SH-SY $5 Y$ cells by up to $50 \%$ (1B; $24-48 \mathrm{~h})$ and by 70\% in SK-N-MC cells (1D; 24-48 h).

VEGF (forward 5'-CCCACTGAGGAGTCCAACAT-3', reverse $5^{\prime}$-TTTCTTGCGCTTTCGTTTTT-3'); ID1 (forward 5'-CTACGACATGAACGGCTGTTACTC$3^{\prime}$, reverse $5^{\prime}$-CTTGCTCACCTTGCGGTTCT-3'); ID2 (forward 5'-TCAGCCTGCATCACCAGAGA-3', reverse $5^{\prime}$-CTGCAAGGACAGGATGCTGAT-3'); ID3 (forward 5'-CTGCAAGGACAGGATGCTGAT-3', reverse $5^{\prime}$-TGGCTCGGCCAGGACTAC-3 ${ }^{\prime}$ ); SNAIL (forward $5^{\prime}$-CTGCGGGAAGGCCTTCTCT-3', reverse $5^{\prime}$-CGCCTGGCACTGGTACTTCTT-3'); SLUG (forward 5'-CGGACCCACACATTACCTTGTGTTT-3', reverse 5'-CACAGCAGCCAGATTCCTCATGTTT$3^{\prime}$ ); TWIST (forward 5'-GGACAAGCTGAGCAAGATTCAGA-3', reverse 5'-TCTGGAGGACCTGGTAGAGGAA- $3^{\prime}$ ). In order to confirm the identity of the amplified genes, $\mathrm{PCR}$ products were then sequenced (DNA-ABI Big Dye Terminator kit, Applied Biosystems, Foster city, CA, USA) and BLAST analysis was performed (data not shown).

\section{Real-time PCR array (human tumor metastasis)}

This method was used to determine if the tumor metastasis-related genes were regulated in response to the experimental conditions described above.
Eighty-four genes (RT ${ }^{2}$ Profiler PCR Array, \# APH028A, Super Array, Inc., Bethesda, MD, USA), including gene involved in cell adhesion, extracellular matrix, cell cycle, cell growth proliferation, apoptosis,

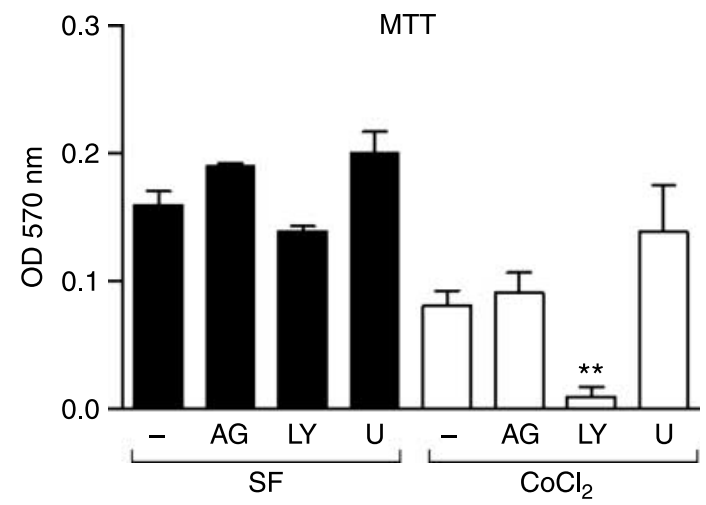

Figure 2 The PI3K sustains mitochondrial functions in hypoxic conditions. Mitochondrial activity (MTT assay) of $\mathrm{SH}-\mathrm{SY} 5 \mathrm{Y}$ cells treated with $\mathrm{CoCl}_{2}$ for $24 \mathrm{~h}$ is decreased by up to $80 \%$ $(P<0.05)$ the presence of the PI3K inhibitor $\left(\mathrm{CoCl}_{2} \mathrm{LY}\right.$ versus $\mathrm{CoCl}_{2}$ untreated '-', or $\mathrm{CoCl}_{2}$ LY versus SF-LY). Blockade of the JAK/STAT (AG) or MAPK (U) pathway did not significantly affect mitochondrial activity of SH-SY5Y cells treated with $\mathrm{CoCl}_{2}$. 
transcription factors, and controls (18SrRNA, RPL13A, HPRT1, $\beta$-actin and GAPDH) were thus simultaneously analyzed. Real-time PCR array was performed twice and experimental samples were generated as per conventional RT-PCR described above. Protocol was as per the manufacturer's specifications.

\section{Statistical analysis}

GraphPad PRISM was utilized to perform one-way ANOVA. Experiments were performed at least thrice or as indicated, with samples run in duplicatequadruplicate for each indicated time and data plotted as mean \pm S.E.M.

\section{Results}

\section{Neuroblastoma cell mitochondrial activity, but not cell number, is decreased by hypoxia}

The two unrelated SH-SY5Y and SK-N-MC neuroblastoma cell lines were treated with hypoxia mimicking agent $\mathrm{CoCl}_{2}(100 \mu \mathrm{M})$ for up to $48 \mathrm{~h}$ (Fig. 1A-D). Cell proliferation or mitochondrial activity was determined by the colorimetric assays NBB or MTT respectively at each of the indicated time points as described in Materials and methods. As shown in Fig. 1A, SH-SY5Y cell number, in either SF or $\mathrm{CoCl}_{2}$, was not significantly decreased $(<5 \%$ Fig. $1 \mathrm{~A})$ over $48 \mathrm{~h}$ while mitochondrial activity was reduced by up to $50 \%(24-48 \mathrm{~h} ; P<0.05)$ by the hypoxic agent, when

A

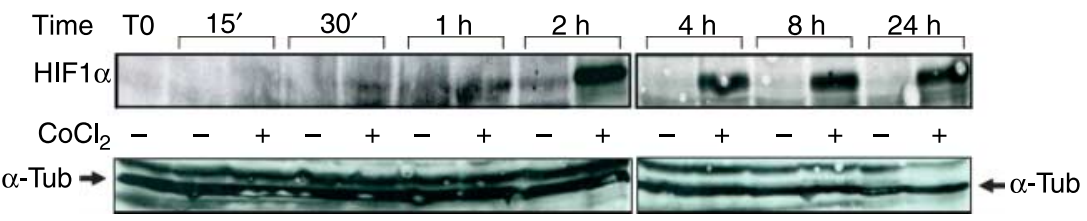

B
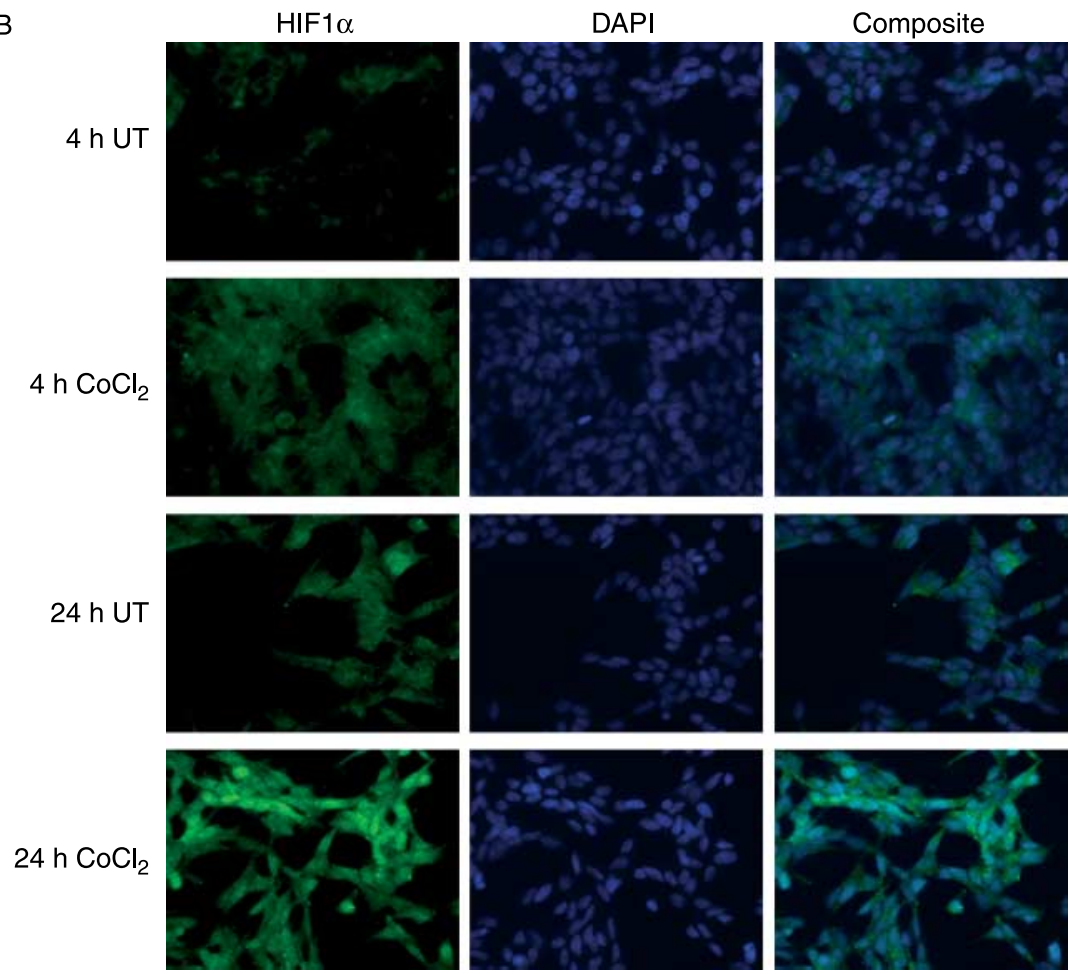

Figure 3 (A and B) Abundance of HIF1 $\alpha$ is increased by hypoxia in SH-SY5Y cells. (A) Cell extract from $\mathrm{CoCl}_{2}$ treated $(+)$, or untreated cells $(-)$ as control, was fractionated onto a $10 \%$ SDS-PAGE transferred to a nitrocellulose filter and probed with anti-HIF1 $\alpha$ antibody as described in Materials and methods. The $\alpha$-tubulin (black arrowhead) was used to verify loading equivalence between samples. HIF1 $\alpha$ was detectable by 30 min post-exposure to hypoxia (T30). (B) HIF1 $\alpha$ accumulation in the nuclear compartments is demonstrated by immunofluorescence with Alexa-488 combined with nuclear DAPI stain as described in Materials and methods. 
compared with that of the untreated (SF) cells. A similar response to $\mathrm{CoCl}_{2}$ was observed in SKNMC cells (Fig. 1C and D). However, SK-N-MC cell number (NBB assay) in SF at $48 \mathrm{~h}$ was significantly increased $(P<0.01)$ to more than that seen in SF conditions at $24 \mathrm{~h}$, while there was no significant difference between $\mathrm{NBB}$ values for $\mathrm{CoCl}_{2}$ treatment at 24 or $48 \mathrm{~h}$ versus SF at $24 \mathrm{~h}$. Mitochondrial activity in SK-N-MC cells was reduced by up to $70 \%(48 \mathrm{~h} ; P<0.01)$ by the hypoxic agent $\mathrm{CoCl}_{2}$ (Fig. $1 \mathrm{C}$ and D) when compared with MTT values is $\mathrm{SF}$ at $24-48 \mathrm{~h}$. Mitochondrial activity (Fig. 1D) in SK-N-MC cells cultured in SF media for $48 \mathrm{~h}$ was increased to more than that seen at $24 \mathrm{~h}$ $(P=0.05)$, consistent with the increase in cell numbers, as determined by the NBB assay (Fig. 1C).

Mitochondrial activity of $\mathrm{CoCl}_{2}$-treated cells was dramatically decreased to $80 \%(P<0.05)$ in the presence of the PI3K inhibitor (Fig. 2; $\mathrm{CoCl}_{2} \mathrm{LY}$ versus $\mathrm{CoCl}_{2}$ untreated '-', or $\mathrm{CoCl}_{2} \mathrm{LY}$ versus SF-LY), suggesting that this pathway is involved in the maintenance of mitochondrial functions in hypoxic conditions. A similar response to PI3K blockade was observed in SK-N-MC cells (data not shown).

\section{Abundance of HIF1 $\alpha$ is increased by hypoxia in SH-SY5Y cells}

The transcriptional complex HIF1, as described earlier, plays an essential role in oxygen homeostasis
(Semenza 1998, Wenger 2002, Safran \& Kaelin 2003, Zarember \& Malech 2005). We therefore investigated whether the response to the hypoxia mimic $\mathrm{CoCl}_{2}$ in neuroblastoma cells would involve modulation of HIF1 $\alpha$ abundance. Cell extract from $\mathrm{CoCl}_{2}$ treated, or untreated cells as control, was fractionated onto a $10 \%$ SDS-PAGE, transferred to a nitrocellulose filter and probed with anti-HIF1 $\alpha$ antibody as described in Materials and methods. In SH-SY5Y cell in serum-free conditions and in the absence of $\mathrm{CoCl}_{2}$ (normoxia), as shown in Fig. 2, levels of HIF1 $\alpha$ were extremely low/undetectable at each of the time points analyzed. HIF1 $\alpha$ was detectable by $30 \mathrm{~min}$ post-exposure to $\mathrm{CoCl}_{2}$ (hypoxia; Fig. 3A, T30). The level of HIF1 $\alpha$ progressively accumulated intracellularly by $2 \mathrm{~h}$ and these levels were maintained for the duration of the experiment $(24 \mathrm{~h})$. HIF $1 \alpha$ protein was similarly induced in SK-N-MC cells. Hypoxia-stabilized HIF1 $\alpha$ appeared to accumulate in the cytoplasm at $4 \mathrm{~h}$ (Fig. $3 \mathrm{~B}, \mathrm{CoCl}_{2}$ ) and translocated to the nuclear compartments as shown at $24 \mathrm{~h}$ (Fig. 3B, $\mathrm{CoCl}_{2}$ ). HIF1 $\alpha$ was not detected in cells cultured in normoxia (Fig. 3B, UT). Cellular localization of HIF1 $\alpha$ in SK-N-MC was not determined. Consistent with IB and IF data, the abundance of HIF1 $\alpha$ mRNA (Fig. 4) in SH-SY5Y cells was significantly increased by $4 \mathrm{~h}$, as per real-time PCR data (Table 1) and maintained up to $24 \mathrm{~h}$. Similar regulation for HIF1 $\alpha$ mRNA was seen in SK-N-MC cells. These findings

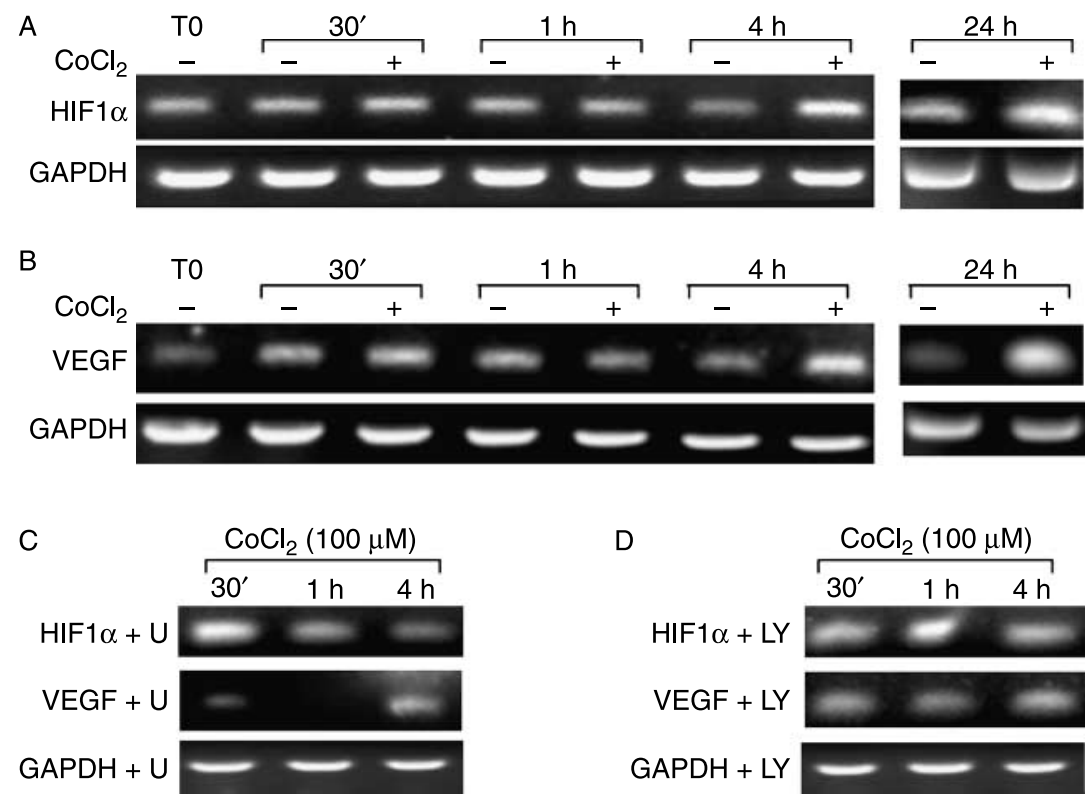

Figure 4 (A-D) The MAPK pathway mediates the induction of HIF1 $\alpha$ and VEGF mRNAs. Following exposure (0-24 h) to the hypoxia mimic agent $\mathrm{CoCl}_{2}$, total RNA was extracted and analyzed as described in Materials and methods. (A) HIF1 $\alpha$ mRNA was increased at 4-24 h, an event modulated by the MAPK pathway (C). (B) VEGF was up-regulated at $4 \mathrm{~h}$. (C and D) The MAPK pathway inhibitor U0126, but not LY294002, modulated VEGF mRNA levels. 
Table 1 Prometastatic gene expression in hypoxic NB cells

\begin{tabular}{|c|c|c|c|}
\hline GeneBank & Symbol & Description & $\begin{array}{l}\text { Fold-change } \mathrm{CoCl}_{2} 4 \mathrm{~h} / \mathrm{SF} \\
4 \mathrm{~h}(\text { c.o. }> \pm 0.5 ; P<0.05)\end{array}$ \\
\hline & & EMT and cell adhesion & \\
\hline NM_004360 & $\mathrm{CDH} 1$ & Cadherin 1, type 1, E-cadherin (epithelial) & 0.48 \\
\hline NM_000038 & APC & Adenomatosis polyposis coli & 0.29 \\
\hline NM_001903 & CTNNA1 & Catenin (cadherin-associated protein)- $\alpha 1,102 \mathrm{kDa}$ & 0.44 \\
\hline NM_002011 & FGFR4 & Fibroblast growth factor receptor 4 & 0.57 \\
\hline NM_000245 & MET/HGF & Met proto-oncogene (hepatocyte growth factor receptor) & 1.43 \\
\hline NM_002206 & ITGA7 & Integrin- $\alpha 7$ & 3.07 \\
\hline NM_000660 & TGFB1 & Transforming growth factor- $\beta 1$ & 1.50 \\
\hline NM_003376 & VEGF & Vascular endothelial growth factor & 5.38 \\
\hline NM_017902 & HIF1 $\alpha$ & Hypoxia inducible factor- $1 \alpha$-subunit & 7.12 \\
\hline NM_005985 & SNAIL & Human homolog of Drosophila Snail & NS \\
\hline NM_003068 & SLUG & Human homolog of Drosophila Slug & NS \\
\hline NM_000474 & TWIST & $\begin{array}{l}\text { Human homolog of Drosophila Twist } \\
\text { Tumor growth and metastasis }\end{array}$ & NS \\
\hline NM_000576 & IL1B & Interleukin-1 $\beta$ & 10.55 \\
\hline NM_002427 & MMP13 & Matrix metallopeptidase 13 (collagenase 3) & 2.34 \\
\hline NM_003256 & TIMP4 & TIMP metallopeptidase inhibitor 4 & 0.34 \\
\hline NM_003467 & CXCR4 & Chemokine (C-X-C motif) receptor 4 & 1.89 \\
\hline NM_003650 & CST7 & $\begin{array}{l}\text { Cystatin F (leukocystatin) } \\
\text { Tumor suppressor }\end{array}$ & 0.52 \\
\hline NM_002256 & KISS1 & KISS1 metastasis-suppressor & 3.50 \\
\hline NM_000077 & CDKN2A & Cyclin-dependent kinase inhibitor $2 \mathrm{~A}$ & 4.14 \\
\hline NM_001846 & COL4A2 & Collagen type IV, $\alpha 2$ & 0.38 \\
\hline NM_004442 & EPHB2 & $\mathrm{EPH}$ receptor $\mathrm{B} 2$ & 0.12 \\
\hline NM_006410 & HTATIP2 & HIV-1 Tat interactive protein 2, $30 \mathrm{kDa}$ & 0.22 \\
\hline
\end{tabular}

suggest that post-transcriptional rather than transcriptional events are responsible for accumulation of HIF $1 \alpha$ protein at the earlier time points $(30 \mathrm{~min}-2 \mathrm{~h}$ ), shown in Fig. 3A. Furthermore, use of the MAPK pathway inhibitor U0126 (Fig. 4C) indicated that this pathway plays a critical role in the up-regulation of HIF $1 \alpha$ mRNA seen at $4 \mathrm{~h}$ (Fig. 4A $4 \mathrm{~h}$ compared with Fig. 4C 4 h). PI3K blockade, using LY294002, had a negligible effect on HIF $1 \alpha$ mRNA levels at $30 \mathrm{~min}$ and $1 \mathrm{~h}$, but had a reproducible inhibition at $4 \mathrm{~h}$ (Fig. $4 \mathrm{~A} 4 \mathrm{~h}$ compared with Fig. 4D 4 h). Pathway blockade and its effect on HIF1 $\alpha$ mRNA level were not performed in SK-N-MC cells.

\section{Abundance of HIF1 $\alpha$ correlates with induction of VEGF}

Newly formed HIF1 complexes (HIF1 $\alpha / \beta)$ interact with the HRE of a large number of target genes including VEGF. We therefore used RT-PCR to analyze the expression of VEGF in response to hypoxia. The time course of expression in hypoxia versus normoxia control samples shows that at $4 \mathrm{~h}$ VEGF mRNA is up-regulated in both SH-SY5Y (Fig. 4A-D) and SK-N-MC cells (Fig. 5). Up-regulation of VEGF mRNA in $\mathrm{CoCl}_{2}$-treated SH-SY5Y cells was also seen at $24 \mathrm{~h}$. The MAPK pathway inhibitor U0126 also affected VEGF mRNA levels (Fig. 4C, 30 min- $1 \mathrm{~h}$ ), while the blockade of the PI3K only minimally affected its expression (Fig. 4D). In similar experiments, $\mathrm{CoCl}_{2}$ treatment also induced the mRNA levels of EPO and its receptor, both targets of HIF1 complex (data not shown). Pathway blockade and its effect on HIF1 $\alpha$ or VEGF mRNA level were not performed in SK-N-MC cells.

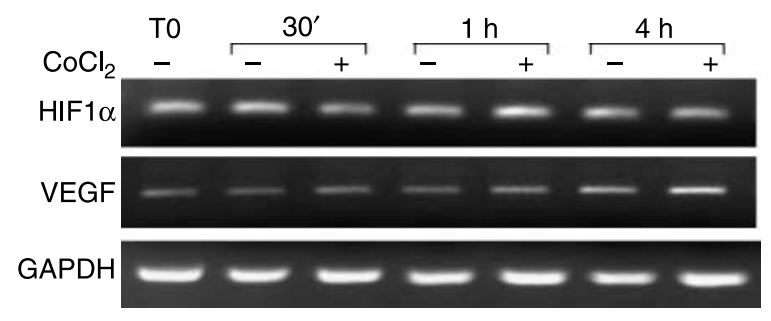

Figure 5 Up-regulation of HIF1 $\alpha$ and VEGF mRNAs in hypoxic SK-N-MC cells. SK-N-MC cells total RNA was extracted and analyzed as described in Materials and methods. HIF1 $\alpha$ mRNA was increased at $1 \mathrm{~h}$, while VEGF mRNA was up-regulated at $4 \mathrm{~h}$ following exposure to the hypoxia mimic agent $\mathrm{CoCl}_{2}$. 


\section{The hypoxia mimic $\mathrm{CoCl}_{2}$ affects abundance and/or cellular localization of Id1-2}

As mentioned earlier, hypoxia promotes dedifferentiation of NB cells back to immature neuroblast-like cells, such that some of genes expressed in the neural crest cells might regain expression in hypoxic NB. The inhibitor of differentiation and DNA binding Id genes (Id1-3) appear to play a key role in these processes. Therefore, the expression of Id1-3 was investigated in SH-SY5Y cells exposed to hypoxic agent $\mathrm{CoCl}_{2}$. The level of gene expression for each of the three genes was not significantly affected by hypoxia over the duration of the experiment $(10 \mathrm{~min}-24 \mathrm{~h}$ time course, not shown). However, cellular localization and abundance for Id 1 and Id2, and to a lesser extent Id3, protein were increased at 4-24 h of hypoxia (Fig. 6A-C, $\mathrm{CoCl}_{2}$ ).

Cellular levels of Id1 were increased at $4 \mathrm{~h}$ with protein mostly localized to the peri-nuclear/nuclear compartment of hypoxic cells (Fig. 6A, $4 \mathrm{~h} \mathrm{CoCl}_{2}$ ). Id 1 staining became localized mostly to the nuclear compartment after $24 \mathrm{~h}$ (Fig. 6B, $4 \mathrm{~h} \mathrm{CoCl}_{2}$ ). In untreated cells (normoxia, UT), Id1 immunoreactivity, at 4 and $24 \mathrm{~h}$, was exclusively located to the cytoplasm (Fig. 6A, $4 \mathrm{~h}-24 \mathrm{~h} \mathrm{UT}$ ). Cellular levels of Id 2 were also increased at $4 \mathrm{~h}$ of hypoxia, with protein localized to the nuclei of most cells (Fig. 6B, $4 \mathrm{~h}$ $\mathrm{CoCl}_{2}$ ). Id 2 protein abundance was further increased at $24 \mathrm{~h}$, and localized to both nuclear and cytoplasm compartments (Fig. 6B, $24 \mathrm{~h} \mathrm{CoCl}_{2}$ ). In untreated cells, Id 2 immunoreactivity, at 4 and $24 \mathrm{~h}$, was exclusively located to the cytoplasm (Fig. 6B, 4 h-24 UT). The levels of nuclear Id 3 were increased more than the time in both untreated (Fig. 6C, 4-24 h UT) and $\mathrm{CoCl}_{2}$ treated cells (Fig. 6C, 4-24 h $\mathrm{CoCl}_{2}$ ), suggesting nuclear accumulation of $\mathrm{Id} 3$ under regulation of other factors, rather than by hypoxia.

\section{Hypoxia promotes the activation of an EMT-like gene expression program in NB cells}

In order to determine if the hypoxia triggers prometastatic processes in NB cells via induction of genes enhancing survival migration and invasion we utilized real-time PCR array.

As shown in Fig. 7 and Table 1, in hypoxic SH-SY5Y NB cells, genes involved in maintenance of cell-cell and cell-matrix interactions (i.e. adenomatosis polyposis coli (APC), E-cadherin, catenin, EphB2, fibronectin-1, HTATIP2, tissue inhibitor of metalloprotease-4) were down-regulated by as much as 90\%. However, Twist, Slug and Snail, other common markers of EMT, were not significantly affected by hypoxia.
A

$$
4 \mathrm{~h} \cup \mathrm{T}
$$

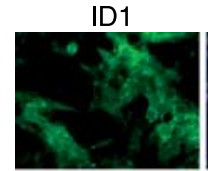

DAPI
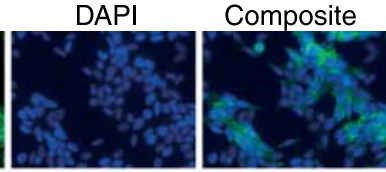

$4 \mathrm{~h} \mathrm{CoCl}_{2}$
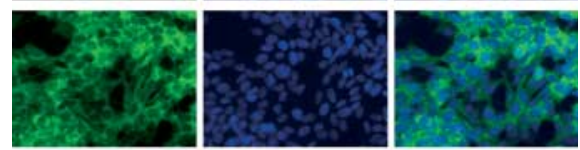

$24 \mathrm{~h}$ UT
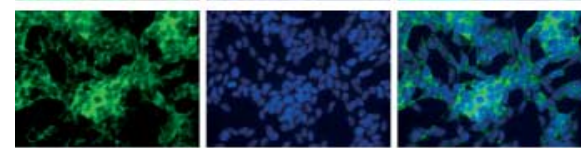

$24 \mathrm{~h} \mathrm{CoCl}_{2}$
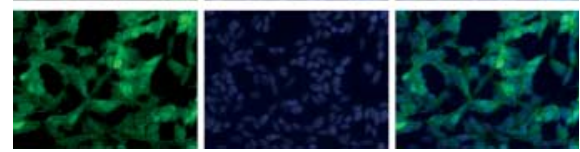

B
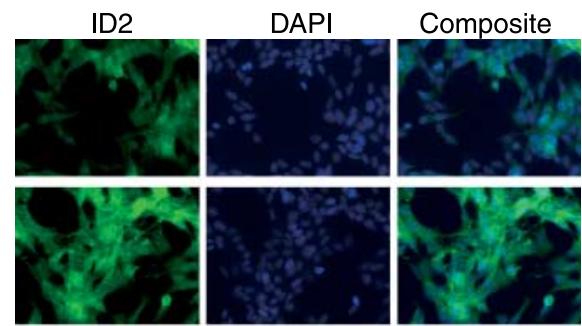

$4 \mathrm{~h} \mathrm{CoCl}_{2}$
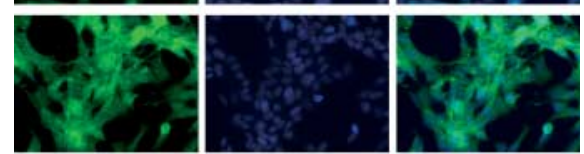

$24 \mathrm{~h}$ UT
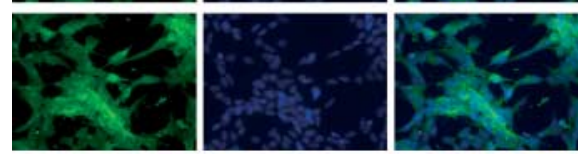

$24 \mathrm{~h} \mathrm{CoCl}_{2}$
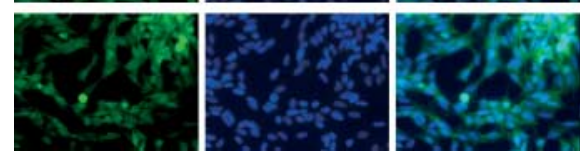

C
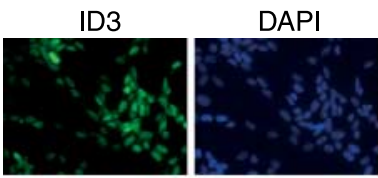

Composite

$4 \mathrm{~h}$ UT
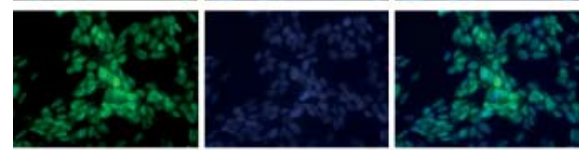

$24 \mathrm{~h}$ UT
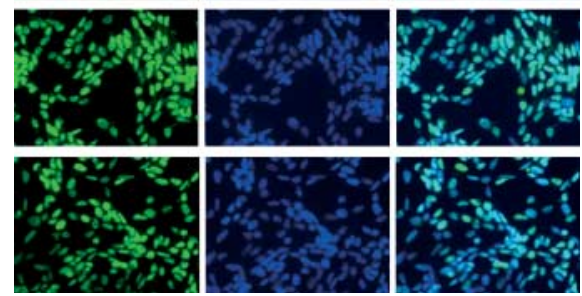

Figure $6(\mathrm{~A}-\mathrm{C})$ Hypoxia induces nuclear accumulation of Id1 and Id2. Immunofluorescence for ID13 was performed as described in Materials and methods. Nuclear localization and abundance for Id13 is shown by Alexa-488 with combined nuclear DAPI stain. 


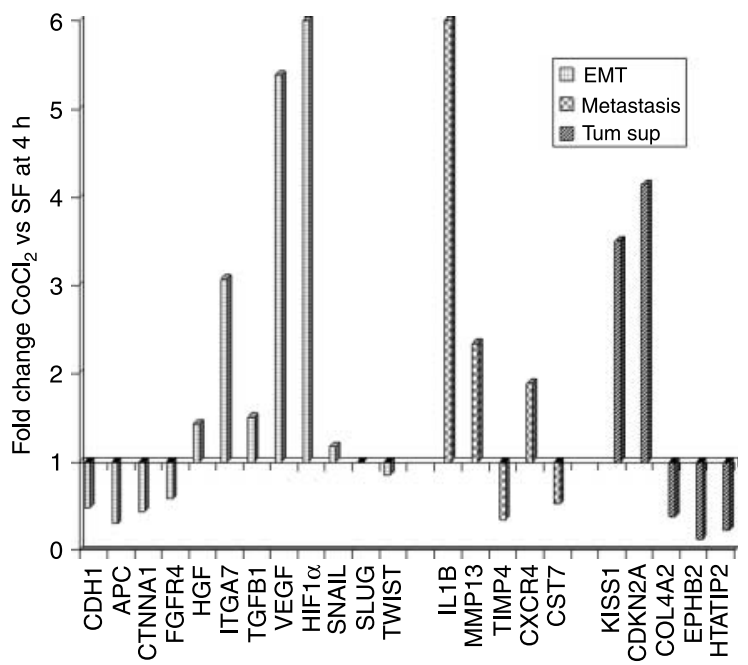

Figure 7 Prometastatic gene expression profile in hypoxic $\mathrm{SH}-\mathrm{SY} 5 \mathrm{Y}$ cells. Real time PCR-Array was performed as described in Materials and methods. Genes involved in maintenance of cell-cell and cell-matrix interactions (APC, E-cadherin, catenin, EphB2, fibronectin-1, HTATIP2, TIMP4) were down-regulated by as much as $90 \%$. Under the same conditions, genes involved in enhancement of metastatic behavior (integrin a7b1, HGF, TGFB1, VEGF, KiSS1, IL1 $\beta$, MMP13) were dramatically up-regulated by over $200 \%$. Realtime PCR data for HIF1 $\alpha$, Snail, Slug and Twist are also included in this graph (see also Table 1).

Under the same conditions, genes involved in enhancement of metastatic behavior (integrin a7b1, hepatocyte growth factor receptor (HGF), transforming growth factor- $\beta 1$, VEGF, kisspeptin (KISS1), Interleukin-1 $\beta$ (IL1 $\beta$ ), matrix metallo protease 13 (MMP13)) were dramatically up-regulated by over $200 \%$.

\section{Discussion}

There is increasing evidence that hypoxia potently influences cellular phenotypes by altering the expression program of specific genes (Harris 2002, Semenza 2003, Brown \& Wilson 2004). A major event in this regulation is the stabilization of the transcription factor HIF1 $\alpha$ leading to the induction of hypoxia responsive genes such as VEGF, one of the most extensively investigated. At normoxia, the HIF $1 \alpha$ subunit is degraded via the proteasomal pathway (Lee et al. 2004, Bardos \& Ashcroft 2005).

In our study, and as previously reported by others (Rossler et al. 1999, Jogi et al. 2004, Das et al. 2005), hypoxia onset by $\mathrm{CoCl}_{2}$ in SH-SY5Y and SK-N-MC cells produced intracellular accumulation of the HIF1 $\alpha$ and associated induction of its target gene VEGF, a process involving MAP kinase signaling. These events are consistent with enhanced cell survival and tumor vascularization (Rossler et al. 1999, Jogi et al. 2004, Das et al. 2005).

Inhibition of the MAPK pathway in $\mathrm{CoCl}_{2}$ treated SHSY5Y cells produced the expected down-regulation of HIF1 $\alpha$ and VEGF expression, while mitochondrial activity (MTT) was not affected by MAPK inhibition. On the other hand, the PI3K inhibitor only minimally affected HIF1 $\alpha$ or VEGF expression. Therefore, activation of the PI3K pathway appears to be responsible for the survival of SH-SY5Y cells in hypoxia, a response likely to be sustained by VEGF signaling, as previously described in these neuroblastoma cell lines (Rossler et al. 1999, Jogi et al. 2004, Das et al. 2005).

A large number of transcription factors are known to be affected by hypoxia via HIF-dependent or -independent mechanism and these include members of the basic-helix-loop-helix family of transcription factors, namely the Id genes (Norton 2000, Jogi et al. 2002, 2004). The levels of mRNA for $I d I$ and $I d 2$ are found up-regulated in some hypoxic neuroblastoma cell lines (Jogi et al. 2002, Lofstedt et al. 2004). Conversely, we found no significant change in $I d$ mRNAs in hypoxic SH-SY5Y neuroblastoma cells, while the protein product of these genes (IdI and Id 2 , but not Id3) accumulated in the nuclei following hypoxia. The absence of effects of hypoxia treatment on the levels of Id 3 gene expression and protein, as we have shown, is however, consistent with that previously reported for Id3 in SH-SY5Y cells by Jogi et al. (2002) and Lofstedt et al. (2004).

The modulation of $I d 2$, as reported in our study, is particularly interesting since it is required for proper neural crest development (Martinsen \& Bronner-Fraser 1998, Jogi et al. 2002). Id2 is directly regulated by HIF1 $\alpha$ (Lofstedt et al. 2004), thus suggesting a link between HIF1 $\alpha$ activation and dedifferentiation of hypoxic neuroblastoma cells.

Chronic exposure to hypoxia mimic agent $(24 \mathrm{~h}$ $\mathrm{CoCl}_{2}$ ) appeared to alter cell morphology, suggesting alterations of cell-cell and cell-matrix interactions and indicating the acquisition of a 'more motile' phenotype, involving events similar to that described for EMT (Thiery \& Sleeman 2006).

It is now well recognized that EMT is a potential mechanism for cancer progression (Huber et al. 2005, Lee et al. 2006, Thiery \& Sleeman 2006) and several signaling pathways have been uncovered, which are common to EMTs in development and tumor progression (Huber et al. 2005, Lee et al. 2006, Thiery \& Sleeman 2006). 


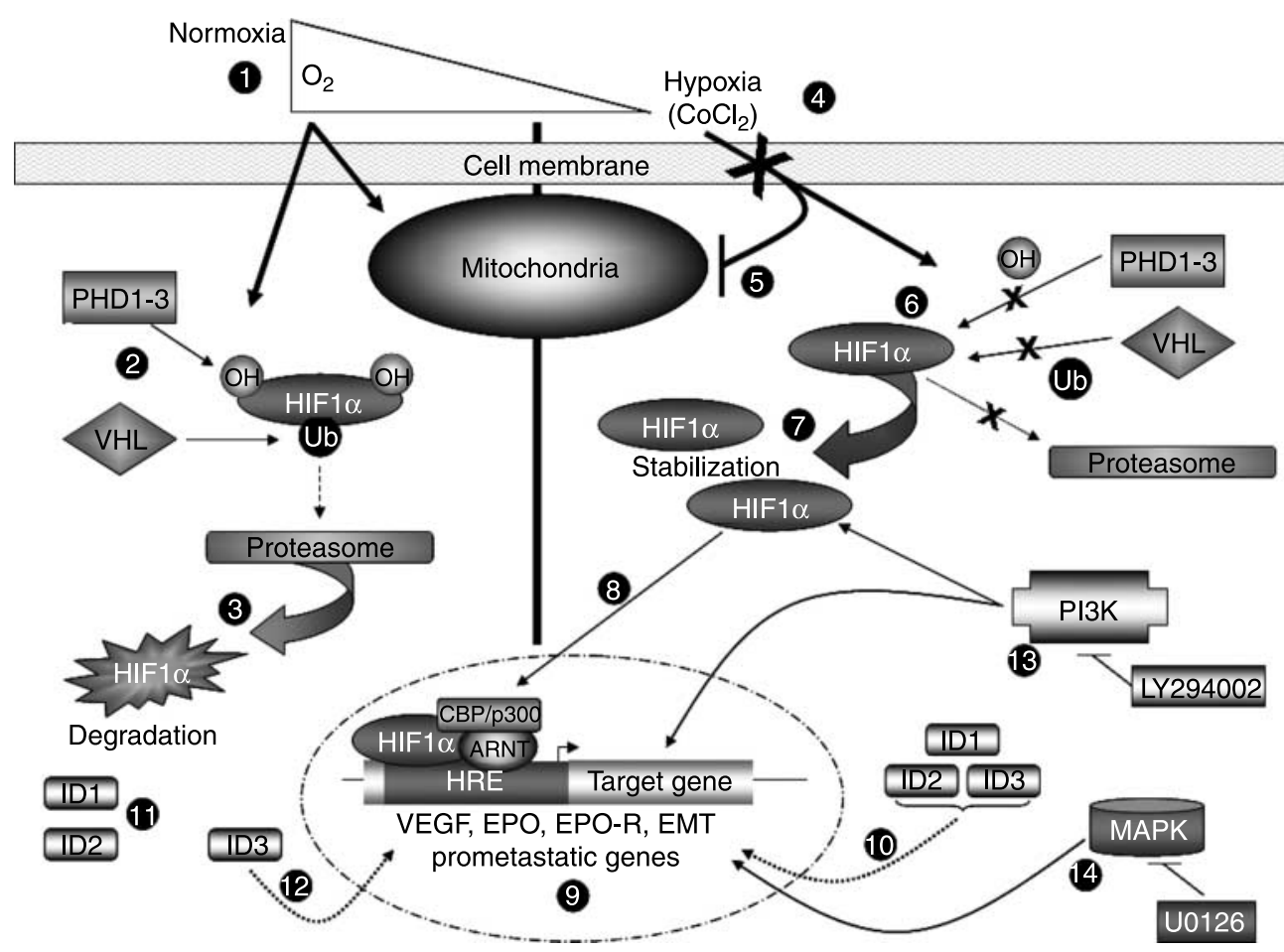

Figure 8 Hypoxia adaptation and prometastatic gene activation in neuroblastoma cells. In solid tumors that become hypoxic because of aberrant newly developed blood vessels and tumor overgrowth, cells often undergo genetic and adaptive changes that allow them to survive and even proliferate in a hypoxic environment. These processes contribute to the malignant and aggressive phenotype. In normoxia (1) mitochondrial activity is optimal and levels of HIF1 $\alpha$ are constitutively regulated at transcriptional, via FIH1 (factor inhibiting HIF1, not shown), and post-translational levels via (2) hydroxylation, ubiquitination and (3) proteasome degradation of HIF1 $\alpha$ protein. In hypoxia (4), mitochondrial activity (5) is decreased and HIF1 $\alpha$ inhibition and degradation are abrogated (6). This leads to a stable and functional HIF1 $\alpha$ (7) and formation of HIF complexes (not shown). These complexes can thus bind to regulatory hypoxia responsive elements (HRE) (8) of genes such as the survival cytokine erythropoietin (EPO) and the angiogenesis factor, vascular endothelial growth factor (VEGF) and genes involved in enhancement of metastatic behavior and EMT-like events (9). The expression level of the Id13 genes was not significantly affected by hypoxia (10), however, cellular levels of Id1 protein were increased within the nuclear compartment of hypoxic cells. In normoxia Id1 and Id2 immunoreactivities (11) was exclusively located to the cytoplasm. The levels of nuclear Id3 were increased over the time in both normoxia (12) and $\mathrm{CoCl}_{2}$ treated cells (10), suggesting nuclear accumulation of Id-3 under regulation of other factors, rather than by hypoxia. The PI3K or the MAPK pathway inhibitors LY294002 (13) and U0126 (14) indicated that these pathways play a critical role in the modulation of HIF1 $\alpha$ mRNA. U0126 (14) also affected VEGF mRNA levels, while the effects of LY294002 (13) were negligible.

In our study, we were able to demonstrate, for the first time in NB cells, that hypoxia strongly downregulated E-cadherin $(\sim 60 \%)$, APC $(\sim 70 \%)$, $\alpha$-catenin $(\sim 60 \%)$, FGFR4 $(50 \%)$ but up-regulated HGF $(\sim 50 \%)$. These regulations are consistent with activation of EMT events (Thiery \& Sleeman 2006) such as the previously reported dissociation of the cell adhesion complex (Bremnes et al. 2002, Ezzat et al. 2004, Blanc et al. 2005), and malignant progression of neuroblastoma (Hecht et al. 2004). Furthermore, the dramatically increased expression of the $\alpha 7 \beta 1$ integrin by up to threefold in hypoxic SH-SY5Y cells suggests the transition of SH-SY5Y cells to a migratory cell phenotype (Gardiner et al. 2005).

TGF- $\beta$ is a major regulator of EMT (Muraoka et al. 2002, Thiery \& Sleeman 2006) and TGF- $\beta 1$ is induced in hypoxic regions of solid tumors (Toomey et al.
2001). It was recently demonstrated (Shah et al. 2006), that transcriptional activation of TGF- $\beta 1$ requires HIF $1 \alpha$. This finding suggests that the up-regulation of TGF- $\beta 1$ expression $(\sim 150 \%)$ observed in our studies, might be a direct consequence of the increase of HIF1 $\alpha$ abundance. Although the up-regulation of TGF- $\beta 1$ and modulation of other genes (E-cadherin, APC, $\alpha$-catenin, VEGF, MMPs, etc.) are consistent with EMT, we found that the expression of Snail, Slug and Twist, other common markers of EMT, was not significantly affected. Whether this indicates that our in vitro system fails to fully mimic the in vivo conditions relevant to the induction of Snail, Slug and Twist, or that the described prometastatic gene expression program leads instead to a EMT-like or an incomplete EMT event, as recently reported by Christiansen \& Rajasekaran (2006), remains unclear. 
The involvement of pro-inflammatory cytokines such as IL-1 $\beta$ in hypoxia response, angiogenesis, tumor growth, and metastasis is largely documented (Apte et al. 2006, Elaraj et al. 2006, Zhang et al. 2006). In our study, IL1 $\beta$ was the most potently up-regulated gene (10 fold) and this might lead to a more aggressive SH-SY5Y cell phenotype, including activation of EMT events (Chaudhuri et al. 2007) and invasion/metastasis (Song et al. 2003). IL-1 $\beta$ promotes expression and release of MMPs, including collagenase MMP13 (Klatt et al. 2006), which is up-regulated in our study.

The induction of MMP13 (2.3 fold) in our studies is intriguing, since this collagenase has an important and specific role in skeletal biology, but its role in neuroblastoma is unknown. Of relevance is that neuroblastoma primary tumor metastases to bone and bone marrow (Cotterill et al. 2000, Russell et al. 2004, 2005), tissues which develop and mature under low ( $\sim 1-2 \%$ ) oxygen (Wang et al. 2007a,b). It is thus likely that in these circumstances metastatic neuroblastoma cells could develop the ability to degrade bone tissue by modulating MMPs (i.e. MMP13) and TIMPs (i.e. TIMP-4, down 2.2 fold), as we have demonstrated in our in vitro hypoxia mimicking model for neuroblastoma cells. A further supportive finding is that chemokine receptor-4 (CXCR4), whose expression in neuroblastoma primary tumors is associated with clinical presentation of bone and bone marrow metastasis (grade 3 and 4; Russell et al. 2004), was up-regulated by $180 \%$ in our study.

Another intriguing finding was the strong up-regulation of two tumor suppressor genes, namely KISS1 and cyclin-dependent kinase inhibitor 2A (CDKN2A, p16/ARF/MTS1). Expression studies for KISS1 in human breast cancer (Martin et al. 2005) and CDKN2A in human colorectal carcinomas (Ohhara et al. 1996) clearly demonstrated that the expression of these two genes is increased in aggressive tumors and also correlates with increased mortality.

Another group of tumor suppressor genes was in contrast strongly down-regulated ( $2-5$ fold) in hypoxic SH-SY5Y cells. This includes the $\alpha 2$ chain of collagen type IV (Kamphaus et al. 2000, Maeshima et al. 2000), the receptor tyrosine kinase Ephrin-B2 (Alazzouzi et al. 2005, Jubb et al. 2005, Davalos et al. 2007), the HIV-1 tat-interacting protein 30 (NicAmhlaoibh \& Shtivelman 2001). The down-regulation or inactivation of these genes has been shown to accelerate tumorigenesis (Kamphaus et al. 2000, Maeshima et al. 2000) disrupt cell-cell adhesion and cell positioning (Alazzouzi et al. 2005, Jubb et al. 2005, Davalos et al. 2007) and increase metastasis and agiogenesis (NicAmhlaoibh \& Shtivelman 2001). Of particular interest is the dramatic down-regulation $(\sim 90 \%)$ of EPHB2 observed in our study. Suppression or inactivation of EPHB2 has been shown to accelerate tumorigenesis initiated by APC mutations in the colon and rectum of $\mathrm{APC}^{\mathrm{Min} /+}$ mice, demonstrating that EPHB2 is an important tumor suppressor in the large intestine (Batlle et al. 2005). The dramatic downregulation of APC $(\sim 80 \%)$ and EPHB2 ( 90\%) observed in our in vitro study is thus consistent with Batlle's in vivo findings (Batlle et al. 2005), and might point to a potential prometastatic synergism of these genes in hypoxic NB cells.

In conclusion (see also Fig. 8), we have demonstrated for the first time that hypoxia in neuroblastoma cells activates a complex prometastatic gene program resembling EMT-like events, contributing to cellular dedifferentiation and transition to an invasive and metastatic NB cell phenotype. This cellular and molecular adaptation is probably promoted by the 'master' hypoxia regulator HIF1 $\alpha$. We therefore propose that similar mechanisms might exist and contribute in vivo to enhancing metastatic behavior of neuroblastoma. Our findings thus point to the identification of new potential candidates for the development of more targeted and or alternative therapies in neuroblastoma.

\section{Declaration of interest}

The authors declare that there is no conflict of interest that could be perceived as prejudicing the impartiality of the research reported.

\section{Funding}

This work was supported by the National Health and Medical Research Council of Australia (NHMRC Project Grant No-436955 to V C R, GAW from 2007 to 2009).

\section{Acknowledgements}

We would like to thank Mr Walid Azar from our laboratory for his technical assistance.

\section{References}

Alazzouzi H, Davalos V, Kokko A, Domingo E, Woerner SM, Wilson AJ, Konrad L, Laiho P, Espin E, Armengol M et al. 2005 Mechanisms of inactivation of the receptor tyrosine kinase EPHB2 in colorectal tumors. Cancer Research 65 10170-10173.

Apte RN, Dotan S, Elkabets M, White MR, Reich E, Carmi Y, Song X, Dvozkin T, Krelin Y \& Voronov E 2006 
The involvement of IL-1 in tumorigenesis, tumor invasiveness, metastasis and tumor-host interactions. Cancer Metastasis Reviews 25 387-408.

Axelson H, Fredlund E, Ovenberger M, Landberg G \& Pahlman S 2005 Hypoxia-induced dedifferentiation of tumor cells - a mechanism behind heterogeneity and aggressiveness of solid tumors. Seminars in Cell \& Developmental Biology 16 554-563.

Bardos JI \& Ashcroft M 2005 Negative and positive regulation of HIF-1: a complex network. Biochimica et Biophysica Acta 1755 107-120.

Batlle E, Bacani J, Begthel H, Jonkheer S, Gregorieff A, van de Born M, Malats N, Sancho E, Boon E, Pawson T et al. $2005 \mathrm{EphB}$ receptor activity suppresses colorectal cancer progression. Nature 435 1126-1130.

Belozerov VE \& Van Meir EG 2005 Hypoxia inducible factor-1: a novel target for cancer therapy. Anticancer Drugs 16 901-909.

Blanc E, Goldschneider D, Douc-Rasy S, Benard J \& Raguenez G 2005 Wnt-5a gene expression in malignant human neuroblasts. Cancer Letters 228 117-123.

Bown N 2001 Neuroblastoma tumour genetics: clinical and biological aspects. Journal of Clinical Pathology 54 897-910.

Bremnes RM, Veve R, Hirsch FR \& Franklin WA 2002 The E-cadherin cell-cell adhesion complex and lung cancer invasion, metastasis, and prognosis. Lung Cancer 36 115-124.

Brodeur GM 2003 Neuroblastoma: biological insights into a clinical enigma. Nature Reviews. Cancer 3 203-216.

Brodeur GM, Seeger RC, Barrett A, Berthold F, Castleberry RP, D’Angio G, De Bernardi B, Evans AE, Favrot M \& Freeman AI 1988 International criteria for diagnosis, staging, and response to treatment in patients with neuroblastoma. Journal of Clinical Oncology 6 1874-1881.

Brown JM \& Wilson WR 2004 Exploiting tumour hypoxia in cancer treatment. Nature Reviews. Cancer 4 437-447.

Bunn HF \& Poyton RO 1996 Oxygen sensing and molecular adaptation to hypoxia. Physiological Reviews $\mathbf{7 6}$ 839-885.

Carmeliet P \& Jain RK 2000 Angiogenesis in cancer and other diseases. Nature 407 249-257.

Chaudhuri V, Zhou L \& Karasek M 2007 Inflammatory cytokines induce the transformation of human dermal microvascular endothelial cells into myofibroblasts: a potential role in skin fibrogenesis. Journal of Cutaneous Pathology 34 146-153.

Chen HH, Su WC, Lin PW, Guo HR \& Lee WY 2007 Hypoxia-inducible factor-1alpha correlates with MET and metastasis in node-negative breast cancer. Breast Cancer Research and Treatment 103 167-175.

Christiansen JJ \& Rajasekaran AK 2006 Reassessing epithelial to mesenchymal transition as a prerequisite for carcinoma invasion and metastasis. Cancer Research 66 8319-8326.
Cotterill SJ, Pearson AD, Pritchard J, Foot AB, Roald B, Kohler JA \& Imeson J 2000 Clinical prognostic factors in 1277 patients with neuroblastoma: results of The European Neuroblastoma Study Group 'Survey' 1982-1992. European Journal of Cancer 36 901-908.

Das B, Yeger H, Tsuchida R, Torkin R, Gee MF, Thorner PS, Shibuya M, Malkin D \& Baruchel S 2005 A hypoxiadriven vascular endothelial growth factor/Flt1 autocrine loop interacts with hypoxia-inducible factor-1alpha through mitogen-activated protein kinase/extracellular signal-regulated kinase 1/2 pathway in neuroblastoma. Cancer Research 65 7267-7275.

Davalos V, Dopeso H, Velho S, Ferreira AM, Cirnes L, Diaz-Chico N, Bilbao C, Ramirez R, Rodriguez G, Falcon O et al. 2007 High EPHB2 mutation rate in gastric but not endometrial tumors with microsatellite instability. Oncogene 26 308-311.

Elaraj DM, Weinreich DM, Varghese S, Puhlmann M, Hewitt SM, Carroll NM, Feldman ED, Turner EM \& Alexander HR 2006 The role of interleukin 1 in growth and metastasis of human cancer xenografts. Clinical Cancer Research 12 1088-1096.

Ezzat S, Zheng L \& Asa SL 2004 Pituitary tumor-derived fibroblast growth factor receptor 4 isoform disrupts neural cell-adhesion molecule/ $N$-cadherin signaling to diminish cell adhesiveness: a mechanism underlying pituitary neoplasia. Molecular Endocrinology 18 2543-2552.

Gardiner NJ, Fernyhough P, Tomlinson DR, Mayer U, von der Mark H \& Streuli CH 2005 Alpha7 integrin mediates neurite outgrowth of distinct populations of adult sensory neurons. Molecular and Cellular Neurosciences 28 229-240.

Harris AL 2002 Hypoxia - a key regulatory factor in tumour growth. Nature Reviews. Cancer 2 38-47.

Hecht M, Papoutsi M, Tran HD, Wilting J \& Schweigerer L 2004 Hepatocyte growth factor/c-Met signaling promotes the progression of experimental human neuroblastomas. Cancer Research 64 6109-6118.

Hockel M \& Vaupel P 2001 Tumor hypoxia: definitions and current clinical, biologic, and molecular aspects. Journal of the National Cancer Institute 93 266-276.

Holmquist L, Jogi A \& Pahlman S 2005 Phenotypic persistence after reoxygenation of hypoxic neuroblastoma cells. International Journal of Cancer 116 218-225.

Holmquist L, Lofstedt T \& Pahlman S 2006 Effect of hypoxia on the tumor phenotype: the neuroblastoma and breast cancer models. Advances in Experimental Medicine and Biology 587 179-193.

Huber MA, Kraut N \& Beug H 2005 Molecular requirements for epithelial-mesenchymal transition during tumor progression. Current Opinion in Cell Biology 17 548-558.

Ikeda E 2005 Cellular response to tissue hypoxia and its involvement in disease progression. Pathology International 55 603-610.

Janet T, Ludecke G, Otten U \& Unsicker K 1995 Heterogeneity of human neuroblastoma cell lines in their 
proliferative responses to basic FGF, NGF, and EGF: correlation with expression of growth factors and growth factor receptors. Journal of Neuroscience Research 40 707-715.

Jogi A, Ora I, Nilsson H, Lindeheim A, Makino Y, Poellinger L, Axelson H \& Pahlman S 2002 Hypoxia alters gene expression in human neuroblastoma cells toward an immature and neural crest-like phenotype. PNAS 99 7021-7026.

Jogi A, Ora I, Nilsson H, Poellinger L, Axelson H \& Pahlman S 2003 Hypoxia-induced dedifferentiation in neuroblastoma cells. Cancer Letters 197 145-150.

Jogi A, Vallon-Christersson J, Holmquist L, Axelson H, Borg A \& Pahlman S 2004 Human neuroblastoma cells exposed to hypoxia: induction of genes associated with growth, survival, and aggressive behavior. Experimental Cell Research 295 469-487.

Jubb AM, Zhong F, Bheddah S, Grabsch HI, Frantz GD, Mueller W, Kavi V, Quirke P, Polakis P \& Koeppen H $2005 \mathrm{EphB} 2$ is a prognostic factor in colorectal cancer. Clinical Cancer Research 11 5181-5187.

Kamphaus GD, Colorado PC, Panka DJ, Hopfer H, Ramchandran R, Torre A, Maeshima Y, Mier JW, Sukhatme VP \& Kalluri R 2000 Canstatin, a novel matrixderived inhibitor of angiogenesis and tumor growth. Journal of Biological Chemistry 275 1209-1215.

Kaur B, Khwaja FW, Severson EA, Matheny SL, Brat DJ \& Van Meir EG 2005 Hypoxia and the hypoxia-induciblefactor pathway in glioma growth and angiogenesis. Neuro-Oncology 7 134-153.

Kitamuro T, Takahashi K, Totsune K, Nakayama M, Murakami O, Hida W, Shirato K \& Shibahara S 2001 Differential expression of adrenomedullin and its receptor component, receptor activity modifying protein (RAMP) 2 during hypoxia in cultured human neuroblastoma cells. Peptides 22 1795-1801.

Klatt AR, Klinger G, Neumuller O, Eidenmuller B, Wagner I, Achenbach T, Aigner T \& Bartnik E 2006 TAK1 downregulation reduces IL-1beta induced expression of MMP13, MMP1 and TNF-alpha. Biomedicine \& Pharmacotherapy 60 55-61.

Lee JW, Bae SH, Jeong JW, Kim SH \& Kim KW 2004 Hypoxia-inducible factor (HIF-1)alpha: its protein stability and biological functions. Experimental \& Molecular Medicine 36 1-12.

Lee JM, Dedhar S, Kalluri R \& Thompson EW 2006 The epithelial-mesenchymal transition: new insights in signaling, development, and disease. Journal of Cell Biology 172 973-981.

Lofstedt T, Jogi A, Sigvardsson M, Gradin K, Poellinger L, Pahlman S \& Axelson H 2004 Induction of ID2 expression by hypoxia-inducible factor-1: a role in dedifferentiation of hypoxic neuroblastoma cells. Journal of Biological Chemistry 279 39223-39231.

Maeshima Y, Colorado PC, Torre A, Holthaus KA, Grunkemeyer JA, Ericksen MB, Hopfer H, Xiao Y, Stillman IE \& Kalluri R 2000 Distinct antitumor properties of a type IV collagen domain derived from basement membrane. Journal of Biological Chemistry 275 21340-21348.

Martin TA, Watkins G \& Jiang WG 2005 KiSS-1 expression in human breast cancer. Clinical \& Experimental Metastasis 22 503-511.

Martinsen BJ \& Bronner-Fraser M 1998 Neural crest specification regulated by the helix-loop-helix repressor Id2. Science 281 988-991.

Mazure NM, Brahimi-Horn MC, Berta MA, Benizri E, Bilton RL, Dayan F, Ginouves A, Berra E \& Pouyssegur J 2004 HIF-1: master and commander of the hypoxic world. A pharmacological approach to its regulation by siRNAs. Biochemical Pharmacology 68 971-980.

Muraoka RS, Dumont N, Ritter CA, Dugger TC, Brantley DM, Chen J, Easterly E, Roebuck LR, Ryan S, Gotwals PJ et al. 2002 Blockade of TGF-beta inhibits mammary tumor cell viability, migration, and metastases. Journal of Clinical Investigation 109 1551-1559.

NicAmhlaoibh R \& Shtivelman E 2001 Metastasis suppressor CC3 inhibits angiogenic properties of tumor cells in vitro. Oncogene 20 270-275.

Norton JD 2000 ID helix-loop-helix proteins in cell growth, differentiation and tumorigenesis. Journal of Cell Science 113 3897-3905.

Ohhara M, Esumi M \& Kurosu Y 1996 Activation but not inactivation of the MTS1 gene is associated with primary colorectal carcinomas. Biochemical and Biophysical Research Communications 226 791-795.

Rossler J, Breit S, Havers W \& Schweigerer L 1999 Vascular endothelial growth factor expression in human neuroblastoma: up-regulation by hypoxia. International Journal of Cancer 81 113-117.

Russell HV, Hicks J, Okcu MF \& Nuchtern JG 2004 CXCR4 expression in neuroblastoma primary tumors is associated with clinical presentation of bone and bone marrow metastases. Journal of Pediatric Surgery 39 1506-1511.

Russell HV, Golding LA, Suell MN, Nuchtern JG \& Strother DR 2005 The role of bone marrow evaluation in the staging of patients with otherwise localized, low-risk neuroblastoma. Pediatric Blood \& Cancer 45 916-919.

Russo VC, Andaloro E, Fornaro SA, Najdovska S, Newgreen DF, Bach LA \& Werther GA $2004 a$ Fibroblast growth factor-2 over-rides insulin-like growth factor-I induced proliferation and cell survival in human neuroblastoma cells. Journal of Cellular Physiology 199 371-380.

Russo VC, Kobayashi K, Najdovska S, Baker NL \& Werther GA $2004 b$ Neuronal protection from glucose deprivation via modulation of glucose transport and inhibition of apoptosis: a role for the insulin-like growth factor system. Brain Research 1009 40-53.

Russo VC, Metaxas S, Kobayashi K, Harris M \& Werther GA 2004c Anti-apoptotic effects of leptin in human neuroblastoma cells. Endocrinology 145 4103-4112. 
Safran M \& Kaelin WG Jr 2003 HIF hydroxylation and the mammalian oxygen-sensing pathway. Journal of Clinical Investigation 111 779-783.

Semenza GL 1998 Hypoxia-inducible factor 1 and the molecular physiology of oxygen homeostasis. Journal of Laboratory and Clinical Medicine $\mathbf{1 3 1}$ 207-214.

Semenza GL 1999 Regulation of mammalian $\mathrm{O}_{2}$ homeostasis by hypoxia-inducible factor 1. Annual Review of Cell and Developmental Biology 15 551-578.

Semenza GL 2003 Targeting HIF-1 for cancer therapy. Nature Reviews. Cancer 3 721-732.

Shah R, Hurley CK \& Posch PE 2006 A molecular mechanism for the differential regulation of TGF-beta1 expression due to the common SNP $-509 \mathrm{C}-\mathrm{T}$ (c-1347C > T). Human Genetics 120 461-469.

Song X, Voronov E, Dvorkin T, Fima E, Cagnano E, Benharroch D, Shendler Y, Bjorkdahl O, Segal S, Dinarello CA et al. 2003 Differential effects of IL-1 $\{$ alpha $\}$ and IL-1 1 beta\} on tumorigenicity patterns and invasiveness. Journal of Immunology 171 6448-6456.

Thiery JP \& Sleeman JP 2006 Complex networks orchestrate epithelial-mesenchymal transitions. Nature Reviews. Molecular Cell Biology 7 131-142.

Toomey D, Condron C, Wu QD, Kay E, Harmey J, Broe P, Kelly C \& Bouchier-Hayes D 2001 TGF-beta1 is elevated in breast cancer tissue and regulates nitric oxide production from a number of cellular sources during hypoxia re-oxygenation injury. British Journal of Biomedical Science 58 177-183.

Wang Y, Wan C, Deng L, Liu X, Cao X, Gilbert SR, Bouxsein ML, Faugere MC, Guldberg RE, Gerstenfeld LC et al. 2007a The hypoxia-inducible factor alpha pathway couples angiogenesis to osteogenesis during skeletal development. Journal of Clinical Investigation 117 1616-1626.

Wang Y, Wan C, Gilbert S \& Clemens T 2007b Oxygen sensing and osteogenesis. Annals of the New York Academy of Sciences 1117 1-11.

Wenger RH 2002 Cellular adaptation to hypoxia: $\mathrm{O}_{2}$-sensing protein hydroxylases, hypoxia-inducible transcription factors, and $\mathrm{O}_{2}$-regulated gene expression. FASEB Journal 16 1151-1162.

Wenger RH, Stiehl DP \& Camenisch G 2005 Integration of oxygen signaling at the consensus HRE. Science's STKE 2005 re12.

Zarember KA \& Malech HL 2005 HIF-1alpha: a master regulator of innate host defenses? Journal of Clinical Investigation 115 1702-1704.

Zhang W, Petrovic JM, Callaghan D, Jones A, Cui H, Howlett C \& Stanimirovic D 2006 Evidence that hypoxiainducible factor-1 (HIF-1) mediates transcriptional activation of interleukin-1beta (IL-1beta) in astrocyte cultures. Journal of Neuroimmunology 174 63-73. 